\title{
Open-air-nesting honey bees Apis dorsata and Apis laboriosa differ from the cavity-nesting Apis mellifera and Apis cerana in brood hygiene behaviour
}

\author{
J. Woyke, ${ }^{\mathrm{a}, *}$ J. Wilde, ${ }^{\mathrm{b}}$ and C.C. Reddy ${ }^{\mathrm{c}}$ \\ a Apicultural Division, Agricultural University, Warsaw, Poland \\ b Apicultural Division, Warmia-Mazury University, Olsztyn, Poland \\ ${ }^{c}$ Zoology Department, Bangalore University, Bangalore, India
}

Received 27 May 2003; accepted 13 January 2004

Available online 9 April 2004

\begin{abstract}
The cavity-nesting Apis mellifera and Apis cerana bees detect, uncap, and remove diseased brood. The hygiene behaviour of openair-nesting bees Apis dorsata and Apis laboriosa was investigated in India and Nepal. Sealed A. dorsata pupae were pin-killed or deep-frozen. The workers removed 73 or $37 \%$ of damaged pin-killed pupae depending on the diameter of the pins, and only $7 \%$ of the frozen undamaged pupae. Migrating $A$. dorsata and $A$. laboriosa left unopened the sealed brood in deserted combs. Thus, $A$. dorsata and $A$. laboriosa do not open undamaged cells with dead brood. This behaviour is a more efficient mechanism in preventing the spread of diseases and parasitic mites than uncapping and removing dead pupae by $A$. mellifera and $A$. cerana. It may be beneficial for migrating $A$. dorsata and $A$. laboriosa to temporarily disuse part of the comb cells in exchange for arresting the mites there and thus reducing the increase of their population.
\end{abstract}

(C) 2004 Elsevier Inc. All rights reserved.

Keywords: Apis dorsata; Apis laboriosa; Tropilaelaps clareae; Hygiene behaviour; Migrations; India; Nepal

\section{Introduction}

The brood of honey bees is subject to different diseases. It is infected by bacteria and viruses and is infested by parasitic mites. Among the most dangerous bacterial diseases is European foul brood (Streptococcus pluton) which cause the death of larvae (unsealed brood) and American foul brood (Baccillus larvae) which kills prepupae and pupae in sealed cells. Two mites Varroa destructor and Tropilaelaps clareae enter brood cells shortly before the cells are sealed and reproduce on prepupae and pupae in sealed cells (Woyke, 1987). After coming out from sealed cells together with emerging worker bees, $V$. destructor can feed on adult bees and survive for several months. However, T. clareae is unable to feed on adult bees and, without brood, die within

\footnotetext{
${ }^{*}$ Corresponding author. Fax: +11-48-22-847-1562.

E-mail address: woyke@alpha.sggw.waw.pl (J. Woyke).
}

a few days (Woyke, 1984, 1985a). Therefore it is dangerous in areas where brood rearing interruption does not occur (Woyke, 1985b).

Honey bees have for long been known to maintain clean and hygienic conditions in their colonies. This important social behaviour encompasses all aspects of detection, uncapping, and removal of dead, diseased and infested larvae and pupae from the combs. This display of hygiene behaviour including its characteristic features was first reported in Apis mellifera (Rothenbuhler, 1964; Spivak and Gilliam, 1998; Woodrow, 1941) and subsequently in the Asian hive bee, Apis cerana (Peng et al., 1987) and the giant wild bee, Apis dorsata (Woyke, 1984, 1996).

Although both the hive (cavity-) nesting and the open-air-nesting bees display hygiene behaviour, it differs significantly from species to species with respect to both quality and quantity. Although $A$. cerana opens cells infested by $V$. destructor it has been reported that 
A. cerana do not remove drone brood infested with $V$. destructor mite (Koeniger et al., 1983; Rath and Dresher, 1990), but instead plugs the pore in the cappings of the dead drone brood (Boecking, 1999). Boecking suggests that the hard cap structure of $A$. cerana drone cells prevents the hygiene behaviour of the nurse bees. Woyke $(1984,1996)$ found sealed cells with $A$. dorsata pupae killed by $T$. clareae within the brood area from which the workers had already emerged. He suggested that $A$. dorsata workers do not open sealed cells with brood killed by $T$. clareae. Koeniger et al. $(1993,2002)$ found a number of capped cells in combs left by colonies, which had migrated and suggested that this may represent a mechanism of mite elimination.

It seems that brood hygiene behaviour of the openair-nesting bees $A$. dorsata and Apis laboriosa differs from that of the cavity-nesting $A$. mellifera and A. cerana.

The purpose of the present investigation is to confirm and describe comprehensively the nature and extent of hygiene behaviour of $A$. dorsata. We investigated also whether similar hygiene behaviour occurs in the closely related open-air-nesting bee $A$. laboriosa.

\section{Materials and methods}

\subsection{Assays of hygienic behaviour of A. dorsata}

The investigations were conducted in March 2002 on three colonies of $A$. dorsata in Bangalore, India: two colonies found in the Jnanabharathi campus and one in the Mysore Education Society College of Bangalore University. Two assays of hygienic behaviour were used, pin and freeze killing. Two pins of different diameters 0.75 and $0.30 \mathrm{~mm}$ were used for killing the sealed pupae. Inserting a pin through the capping of $A$. dorsata killed pupae in sealed brood. For the freeze assay method, three pieces of sealed brood were carefully cut and removed from three test nests of $A$. dorsata. Two pieces were shaped as equilateral triangles of 7 and $10 \mathrm{~cm}$ sides and the third one was an obtuse triangle of $6 \times 9 \times 12 \mathrm{~cm}$. Pupae on the edges of combs were cut and damaged during the process of removal and insertion of the comb pieces. There were about 120, 290, and 350 pupae, respectively, in the three test comb pieces. Keeping the brood in a freezer at $-20^{\circ} \mathrm{C}$ for $24 \mathrm{~h}$ killed the pupae in the combs, which afterwards were inserted into the respective test nests. Brood killed by either method was checked daily for 5 days in colonies No. 1 and 2 and for 4 days in colony No. 3. The number of pupae left and the nature of cell capping on brood cells of test comb pieces was recorded daily throughout the observation.

For control purposes, the sealed cells were counted that remained in all three colonies within the brood area of 400 cells from which worker bees emerged.
2.2. Observation of sealed brood left behind in combs deserted by Apis dorsata

We also compared the results of hygiene behaviour towards brood killed by us artificially with that towards brood killed naturally by mites and diseases. For that purpose, we examined recently deserted combs on a banyan tree on the Agricultural University campus in Bangalore. We observed the colonies continuously from 9:00 to 17:00 h, during 10 days (4-13 March, 2002). We wanted to check the presence of sealed brood cells in combs immediately after the combs were deserted by $A$. dorsata colonies. We counted or estimated the number of sealed cells in abandoned combs.

\subsection{Observation of sealed brood left behind in combs deserted by Apis laboriosa}

To gain some idea on brood hygiene behaviour in the closely related open-air-nesting A. laboriosa, we searched for recently deserted empty combs. The observations were conducted in 1999/2000 in the Himalayas in Nepal in Chale (lat. $28^{\circ} 09^{\prime} \mathrm{N}$ and long. $85^{\circ} 48^{\prime}$ ) near the Tibetan border while investigating the biology of that bee (Woyke et al., 2001c, 2003). We also counted or estimated here the number of cells with sealed brood in combs abandoned by $A$. laboriosa colonies.

The combs in both places at the banyan tree and on the rock cliffs were observed with the aid of $12 \times 50$ binoculars. They were also photographed and videorecorded (zoom $24 \times$ ).

\subsection{Examination of brood combs cut from A. laboriosa nests}

In the Himalayas in Chale, we cut brood combs from two $A$. laboriosa colonies. We brought those combs to Dabur Apicultural Centre in Jugedi, Chitwan. Here we opened the cappings and examined, under a stereo microscope, the contents of 400 sealed brood cells from colony 1 and 300 from colony 2 . More cells were examined from the first colony because, after opening, more dead brood was found there.

\subsection{Statistical analysis}

ANOVA was applied. For statistical calculations, percentages were transformed according to arcsine function. The Duncan multiple range test was used to detect significant differences between the means. Values were recognized as significantly different when $P<0.01$. 


\section{Results}

\subsection{Effect of hygiene behaviour of A. dorsata workers toward brood killed artificially or naturally}

Out of 156 pupae killed with the thick pin $(0.75 \mathrm{~mm})$ and 193 killed with the thin pin $(0.30 \mathrm{~mm})$, only 26.4 and $63.0 \%$, respectively, were still found in their cells the next day (Table 1) The proportion of pupae removed from cells pinned with the thick pin was highly significantly more than from those treated with the thin pin. During the next five days, the number of removed brood did not change. Cappings on pin-treated cells were not damaged or even scratched by the bees throughout the rest of the observations.

The next day after the insertion of freeze-killed brood, pupae were found to have been removed from all damaged cells along the edges of the inserts. There still remained 100-310 sealed pupae per freeze-killed replicate (Table 1). After 4 days, $95 \%$ of pupae remained in colonies 2 and 3, and a few percent less in colony 1 . Mainly pupae on the edges of the inserts had been removed. In colony 1 , bees removed capped pupae from near one edge, but not in the other colonies. In the central portion of the brood pieces, only 1 pupa was removed in each of colonies 2 and 3, and 7 in colony 1 .

Table 1

Hygiene behaviour of $A$. dorsata workers toward pierced or frozen brood

\begin{tabular}{|c|c|c|c|}
\hline \multicolumn{4}{|c|}{ Pin-killed pupae } \\
\hline \multirow[t]{2}{*}{ Repetition } & \multirow[t]{2}{*}{ Killed No. } & \multicolumn{2}{|c|}{ Left next day } \\
\hline & & No. & $\% \pm \mathrm{SE}$ \\
\hline \multicolumn{4}{|c|}{ Thick pin, diameter $0.75 \mathrm{~mm}$} \\
\hline 1 & 106 & 39 & 36.8 \\
\hline 2 & 50 & 8 & 16.0 \\
\hline Total & 156 & 47 & $26.4 \mathrm{a} \pm 10.4$ \\
\hline \multicolumn{4}{|c|}{ Thin pin, diameter $0.30 \mathrm{~mm}$} \\
\hline 1 & 68 & 40 & 58.8 \\
\hline 2 & 45 & 32 & 71.1 \\
\hline 3 & 50 & 36 & 72.0 \\
\hline 4 & 30 & 15 & 50.0 \\
\hline Total & 213 & 123 & $63.0 \mathrm{~b} \pm 5.3$ \\
\hline \multicolumn{4}{|c|}{ Freeze-killed pupae } \\
\hline \multirow[t]{2}{*}{ Col. No. } & \multirow{2}{*}{$\begin{array}{l}\text { Left next day } \\
\text { No. }\end{array}$} & \multicolumn{2}{|c|}{ Left after 4 days } \\
\hline & & No. & $\% \pm \mathrm{SE}$ \\
\hline 1 & 100 & 90 & 90.0 \\
\hline 2 & 265 & 250 & 94.3 \\
\hline 3 & 310 & 294 & 94.8 \\
\hline Total & 675 & 634 & $93.0 \mathrm{c} \pm 1.5$ \\
\hline
\end{tabular}

Different letters after means indicate significant differences between them $P<0.01$. The $\%$ of pin-killed pupae left the next day and after 4 days was the same.
There was no change in the number of pupae left in colonies No. 1 and 2 on the next (fifth) day. Cappings on all cells remained intact till the end of the observations. The cells were not opened by the bees even after all the workers emerged from brood area around the insert in colony No. 1. Highly significantly, more brood was left in comb cells with freeze-killed pupae than with those killed by pins of either size.

Within the control areas of 400 cells from which worker bees emerged, $0.75,0.75$, and $1 \%$ cells remained unopened in combs of colonies 1, 2, and 3 respectively. We cut pieces of brood comb from colony 3 . We found there $T$. clareae mites in very few sealed brood cells. Unfortunately the exact number was not recorded.

Thus, all the results show that $A$. dorsata workers did not open undamaged sealed cells containing artificially killed brood.

\subsection{Effect of hygiene behaviour of A. dorsata workers toward naturally killed brood}

In the banyan tree, there were $98 \mathrm{~A}$. dorsata nests. Additionally, we found there 45 recently abandoned combs. During the next 10 days of our observations 11 colonies absconded in our presence and we were able to record the number of sealed cells without any outside interference. In most combs, we found only a few (10 40) unopened cells, which displayed an infestation level below $1 \%$ of the number of brood cells. However, two colonies, which absconded in our presence, left combs with many sealed cells. Both combs were relatively small (approximately $55 \times 55 \mathrm{~cm}$ ) in comparison to the other combs $(75-150 \times 60-100 \mathrm{~cm}, \bar{x} \pm \mathrm{SD}=109 \pm 24 \times 84 \pm$ $15 \mathrm{~cm}, n=8)$. On one side of the first comb, we recorded $390(30 \%)$ sealed cells within a brood area of 1280 cells. In the second comb, we found 475 sealed cells $(31 \%)$ within 1530 brood cells on one side of the comb. These two colonies were so small probably due to a high infestation level.

All the results show that $A$. dorsata did not open undamaged sealed cells containing brood killed artificially or naturally.

\subsection{Effect of hygiene behaviour of A. laboriosa workers towards naturally killed brood}

We found a rock cliff with 53 A. laboriosa nests in Chale near the Tibetan border. In addition there were four recently abandoned combs of a light brown colour. We recorded 750 sealed brood cells left at one side of the comb 1 (size about $60 \times 60 \mathrm{~cm}$ ). Thus, a total of 1500 sealed cells were left at both sides of that comb. They presented $40 \%$ of the total number of cells in the brood area. Comb 2, about the same size, contained 980 sealed cells at one side. Thus, 1960 sealed brood cells were left 
at that comb. They represented $50 \%$ of cells in the brood area. In the other two combs, Nos. 3 and $4(40 \times 30 \mathrm{~cm})$, $5 \%$ sealed brood cells were left.

We found also a rock cliff with $15 \mathrm{~A}$. laboriosa nests, $8 \mathrm{~km}$ apart, in the direction of the Tibetan border. Additionally there was one recently deserted comb with $40 \%$ of cells occupied by sealed brood. The results show that $A$. laboriosa leaves sealed brood cells in abandoned combs.

\subsection{Infestation of brood cells in combs cut from $A$. laboriosa nests}

We examined pieces of brood combs cut from two $A$. laboriosa nests. Within 400 sealed brood cells in a comb from the first colony we found $30 \%$ sealed cells containing dead brood. The cappings of the cells were not damaged. Dead mites, both T. clareae as well as Tropilaelaps koenigerum, were present in most cells. However, inside some cells with dead brood, we did not find any mites. It looked as if the brood had died due to some disease. Within 300 sealed cells in the comb from the second colony only $10 \%$ contained dead brood.

Thus, A. laboriosa did not open sealed cells with brood killed by mites and, presumably, some brood diseases.

\section{Discussion}

A. mellifera bees are considered hygienic if they remove over $95 \%$ of dead brood within $48 \mathrm{~h}$ (Spivak and Gilliam, 1998). Our results indicate that $A$. dorsata removed part of the brood killed by the pin method within $24 \mathrm{~h}$. More brood was removed when cell cappings were pinned with the thicker pin. This suggests that the greater damage caused to cell cappings, as well as larger amount of haemolymph which had oozed out from the body of pupae pierced with larger pin, was the cause of the increased removal. The spreading of haemolymph from injured pupae and the corresponding increase in the rate of removal of killed pupae in A. dorsata is in agreement with the earlier findings on $A$. mellifera (Gramacho et al., 1999; Spivak and Downey, 1998). However, the next day we did not see the holes left in the cell cappings during the piercing of the pupae. Probably the small holes were resealed. In the following days of observation $A$. dorsata did not remove the rest of the pin-killed brood. This suggests that dead brood in cells with undamaged cappings is not removed. In the freezekilled brood, only physically damaged pupae were removed. The disappearance of pupae from one edge of the insert in colony No. 1 in the next days suggests that the parts of cells, including cappings, may get damaged during the process of cutting, removal and insertion of the comb piece into the experimental nest. Capping on other cells with dead brood in all 3 nests were not even scratched during next 4 days, even after the emergence of brood around the insert. Thus, the present study shows that $A$. dorsata does not make any attempt to open cells with undamaged cappings to remove dead brood.

The results support the findings of Woyke et al. (2000, 2001a, 2002) that workers of $A$. dorsata did not open cells or did not even try to scratch the cappings on introduced sealed brood of two other Apis species, A. mellifera and A. cerana. On the contrary, both A. mellifera and $A$. cerana opened the capping of cells on introduced sealed brood of $A$. dorsata within a few hours.

Examination of cells of $A$. dorsata infected with $T$. clareae at Pune, India in 1974 (by J. Woyke) revealed interesting information on mite infestation. Pupae were not killed when they were invaded by a few mites but were killed if invaded by many mites (14 mites/cell). According to Woyke $(1984,1996)$ A. dorsata did not open cells with pupae killed by $T$. clareae within the brood area. Koeniger et al. $(1993,2002)$ reported that the cells remained unopened even after the emergence of all brood and the emigration of the bees. Rath and Delfinado-Baker (1991) and Koeniger et al. (2002) did not found nymphs of $T$. clareae in the debris of $A$. dorsata colonies. This indicates that sealed cells with brood containing different development stages of $T$. clareae were not opened.

We found also sealed brood cells in combs abandoned by $A$. laboriosa. Brood in A. dorsata and A. laboriosa nests may also be killed by bacterial diseases (Allen et al., 1990). The increased removal of brood killed by the larger pin when more haemolymph oozed out may suggest that cappings soaked by liquid from disease-killed, decomposed, brood may be opened.

Thus, mites would spread within $A$. dorsata and $A$. laboriosa colonies from parasitic female mites, which came out with emerging worker bees that survived the infestation. Bacterial and viral diseases would spread from cells with changed cappings, which provoked the bees to open them.

However, A. dorsata and A. laboriosa do not open cells with undamaged cappings containing dead or strange brood. Comparatively, the non-opening of diseased or killed brood is indeed a more efficient method of hygiene behaviour than opening, as opening results in the release of bacteria and mites which in turn enter a healthy neighbouring brood (Boecking and Drescher, 1993).

Thus, including the present results, three types of eliminating mites and diseases from $A$. dorsata and $A$. laboriosa nests may be presented.

First, A. dorsata actively grooms and hunts for $T$. clareae outside sealed brood cells (Koeniger et al., 2002; Koeniger and Muzafar, 1988; Rath and Delfinado-Baker, 1991). 
A second mechanism presented here is that $A$. dorsata and $A$. laboriosa do not open cells with dead brood. As a result, the mites cannot escape from infected cells. A high percentage of sealed cells with dead brood and lack of adequate space for bee reproduction may cause the colonies to migrate. However, migration of bees does not eliminate from the colonies mites left behind in deserted combs in sealed cells with dead brood. Those cells would not have been opened and the mites would not have come out, even if the bees did not migrate.

In the third type of mechanism, migration of $A$. dorsata and $A$. laboriosa indirectly eliminates large number of mites. Migration of colonies causes the cessation of egg-laying activity of the queen, which diminishes the amount of brood and, finally, results in its absence (Woyke et al., 2001b). Even mites emerging along with worker bees from sealed brood cannot survive for more than a few days on adult bees (Aggarwal, 1988; Koeniger and Muzafar, 1988; Woyke, 1984). As a result, a heavy fall in the number of mites occurs from A. dorsata colonies shortly before migration (Koeniger et al., 2002; Rath and Delfinado-Baker, 1991). Therefore, mites are absent in new arriving colonies (Kavinseksan et al., 2003). The new swarms arrive at a new site within a period of several weeks or even several months (Woyke et al., 2001a). They may become infested again by mites from established colonies due to bee drifting or robbing (Paar et al., 2002).

The final question is, what advantages may be achieved by $A$. dorsata and $A$. laboriosa from not opening sealed cells with dead brood, and what advantages by $A$. mellifera and $A$. cerana from opening sealed cells and removing infected or infested brood. The first species are open-air-nesting and migratory. It may be beneficial for them to disuse temporarily part of the comb cells in exchange for arresting the mites there and thus reducing the increase of their population. When the number of disused cells becomes too high, and the bee reproducing area is insufficient, the bees abscond.

However, the cavity-nesting species do not migrate $(A$. mellifera), or migrate less frequently (A. cerana). They cannot withstand the disuse of a large part of brood comb for a long period. For them it is more beneficial to remove dead brood together with some mites, bacteria, and viruses, and use the cells for bee brood rearing.

\section{Acknowledgments}

We would like to thank very much Dr. N.N. Nagaraja for his valuable help during these investigations. We thank also two anonymous reviewers for their comments, which helped to improve the manuscript.

\section{References}

Aggarwal, K., 1988. Incidence of Tropilaelaps clareae on three Apis species in Hisar India. In: Needham, G.R., Page, R.E., DelfinadoBaker, M., Bowman, C.E. (Eds.), Africanized Honey Bees and Bee Mites. Ellis Horwood Lim, Chichester, pp. 396-403.

Allen, M.F., Ball, B.V., Underwood, B.A., 1990. An isolation of Mellissoccocus pluton from Apis laboriosa. J. Invertebr. Pathol. 53, 439-440.

Boecking, O., 1999. Sealing up and non-removal of diseased and Varroa jacobsoni infested drone brood cells is part of the hygienic behaviour in Apis cerana. J. Apic. Res. 38, 159-168.

Boecking, O., Drescher, W., 1993. Preliminary data on the response of Apis mellifera to brood infested with Varroa jacobsoni and the effect of this resistance mechanism. In: Connor, L.J., Rinderer, T., Silvester, H.A., Wongsiri, S. (Eds.), Asian Apiculture. Wicwas Press, Cheshire, CT, USA, pp. 454-462.

Gramacho, K.P., Gonçalves, L.S., Rosenkranz, P., De Jong, D., 1999. Influence of body fluid from pin-killed honey bee pupae on hygienic behaviour. Apidologie 30, 367-374.

Kavinseksan, B., Wongsiri, S., Guzman De, L.I., Rinderer, T.E., 2003. Absence of Tropilaelaps infestation from recent swarms of Apis dorsata in Thailand. J. Apic. Res. 42, 49-50.

Koeniger, N., Koeniger, G,, Delfinado-Baker, M., 1983. Observations on mites of the Asian honeybee species. Apidologie 14, 197204

Koeniger, N., Koeniger, G., Mardan, M., Wongsiri, S., 1993. Possible effects of regular treatments of varroatosis on the host-parasite relationship between $A$. mellifera and Varroa jacobsoni. In: Connor, L.J., Rinderer, T., Sylvester, H.A., Wongsiri S. (Eds.), Asian Apiculture, Int. Conf. on Asian Honey Bees and Bee Mites, Bangkok, 1992, pp. 541-550.

Koeniger, G., Koeniger, N., Anderson, D.L., Lekprayoon, Ch., Tingek, S., 2002. Mites from debris and brood cells of Apis dorsata colonies in Sabah (Borneo) Malaysia, including a new halotype of Varroa jacobsoni. Apidologie 33, 15-24.

Koeniger, N., Muzafar, N., 1988. Lifespan of the parasitic honey bee mite Tropilaelaps clareae on Apis cerana, dorsata and mellifera. J. Apic. Res. 27, 207-212.

Paar, J., Oldroyd, B.P., Huettinger, E., Kastberger, G., 2002. Drifting of workers in nest aggregation of the giant honeybee Apis dorsata. Apidologie 33, 553-561.

Peng, Y., Fang, Y., Xu, S., Ge, L., Nasr, M.E., 1987. Response of foster Asian honey bee (Apis cerana Fabr.) colonies to the brood of European honey bee (Apis mellifera) infested with parasitic mite Varroa jacobsoni Oudemans. J. Invertebr. Pathol. 49, 259-264.

Rath, W., Dresher, W., 1990. Response of Apis cerana Fab. towards brood infested with Varroa jacobsoni Oud. and infestation rate of colonies in Thailand. Apidologie 21, 311-321.

Rath, W., Delfinado-Baker, M., 1991. Analysis of Tropilaelaps clareae populations collected from the debris of Apis dorsata and Apis mellifera. In: Proc. Int. Symp. Recent Res. Bee Pathology, Ghent 1990, Belgium, pp. 86-89.

Rothenbuhler, W., 1964. Behaviour genetics of nest cleaning in honeybees. IV Response of $F_{1}$ and backcross generations to disease-killed brood. Am. Zool. 4, 111-123.

Spivak, M., Downey, D.L., 1998. Field assays for hygienic behaviour in honey bees (Apidae: Hymenoptera). J. Econ. Entomol. 91, 64-70.

Spivak, M., Gilliam, M., 1998. Hygienic behaviour of honey bees and its application for control of brood diseases and Varroa. Bee World, 124-134, 169-186.

Woodrow, A.W., 1941. Behavior of honeybees toward brood infected with American foulbrood. Am. Bee J. 81, 363-366.

Woyke, J., 1984. Survival and prophylactic control of Tropilaelaps clareae infesting Apis mellifera colonies in Afghanistan. Apidologie $15,421-434$ 
Woyke, J., 1985a. Tropilaelaps clareae in Afghanistan, and control methods applicable in tropical Asia. In: Proc. 3rd Int. Conf. Apic. Trop. Climates, Nairobi, pp. 163-166.

Woyke, J., 1985b. Tropilaelaps clareae, a serious pest of Apis mellifera in the tropics, but not dangerous for apiculture in temperate zones. Am. Bee J. 125, 497-499.

Woyke, J., 1987. Length of stay of the parasitic mite Tropilaelaps clareae outside sealed honeybee brood cells as a basis for its effective control. J. Apic. Res. 26, 104-109.

Woyke, J., 1996. Different reaction of Apis dorsata and Apis mellifera to brood infestation by parasitic mites. In: Proc 3rd AAA Conf. on Bee Res. and Beekeeping Dev., Hanoi, Vietnam, pp. $172-175$.

Woyke, J., Wilde, J., Wilde, M., 2000. Genetic versus environmental cues used in recognition and acceptance of two honeybee species, Apis mellifera and Apis dorsata in the same colony. Pszczeln. Zesz. Nauk. 44, 67-80.
Woyke, J., Wilde, J., Wilde, M., 2001a. Coexistence of Apis mellifera and Apis dorsata workers in the same colonies. In: Proc. VII IBRA Conference on Tropical Bees, and V Asian Apicultural Association Conference, Chiang Mai, 19-25 March, 2000, pp. 115-120.

Woyke, J., Wilde, J., Wilde, M., 2001b. Swarming, migration and absconding of Apis dorsata colonies. In: Proc. VII Internat. Conf. on Tropical Bees, and V Asian Apicult. Assoc. Conf., Chiang Mai, 19-25 March, 2000, pp. 183-188.

Woyke, J., Wilde, J., Wilde, M., 2001c. A scientific note on Apis laboriosa winter nesting and brood rearing in the warm zone of Himalayas. Apidologie 32, 601-662.

Woyke, J., Wilde, J., Wilde, M., 2002. Heritable versus environmental cues in recognition and acceptance of two species of honeybees: Apis cerana and Apis dorsata in one colony. 6th Asian Apicult. Assoc. Intern. Conf., Bangalore, India, p. 8.

Woyke, J., Wilde, J., Wilde, M., 2003. Periodic mass flights of Apis laboriosa in Nepal. Apidologie 34, 121-127. 